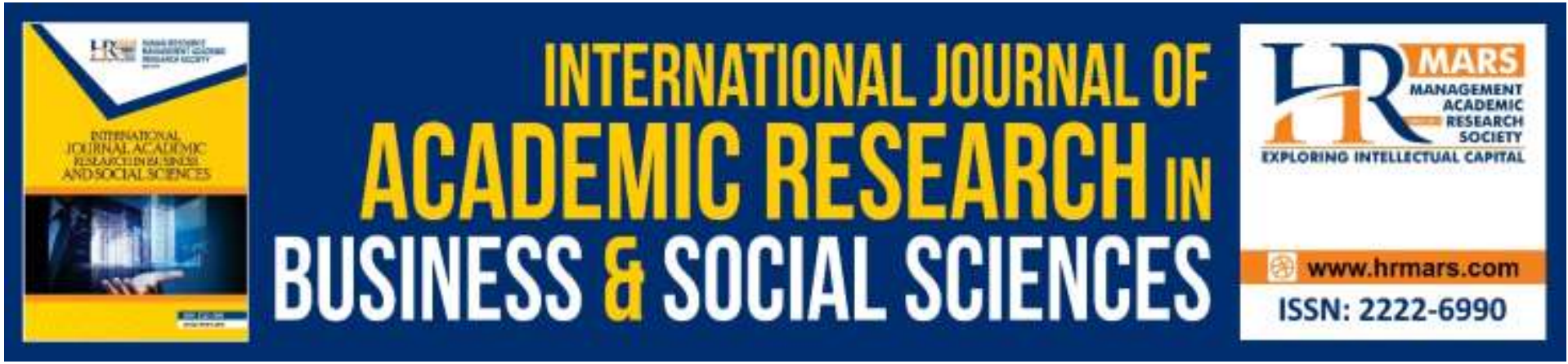

\title{
Indie Phenomenon: Sustainability of Malay Literature
}

\section{Sim Chee Cheang}

To Link this Article: http://dx.doi.org/10.6007/IJARBSS/v9-i9/6292

DOI: $10.6007 /$ IJARBSS/v9-i9/6292

Received: 12 July 2019, Revised: 29 July 2019, Accepted: 30 August 2019

Published Online: 03 September 2019

In-Text Citation: (Cheang, 2019)

To Cite this Article: Cheang, S. C. (2019). Indie Phenomenon: Sustainability of Malay Literature. International Journal of Academic Research in Business and Social Sciences, 9(9), 273-281.

\section{Copyright: (C) 2019 The Author(s)}

Published by Human Resource Management Academic Research Society (www.hrmars.com)

This article is published under the Creative Commons Attribution (CC BY 4.0) license. Anyone may reproduce, distribute, translate and create derivative works of this article (for both commercial and non-commercial purposes), subject to full attribution to the original publication and authors. The full terms of this license may be seen

at: http://creativecommons.org/licences/by/4.0/legalcode

Vol. 9, No. 9, 2019, Pg. 273 - 281

http://hrmars.com/index.php/pages/detail/IJARBSS

JOURNAL HOMEPAGE

Full Terms \& Conditions of access and use can be found at http://hrmars.com/index.php/pages/detail/publication-ethics 


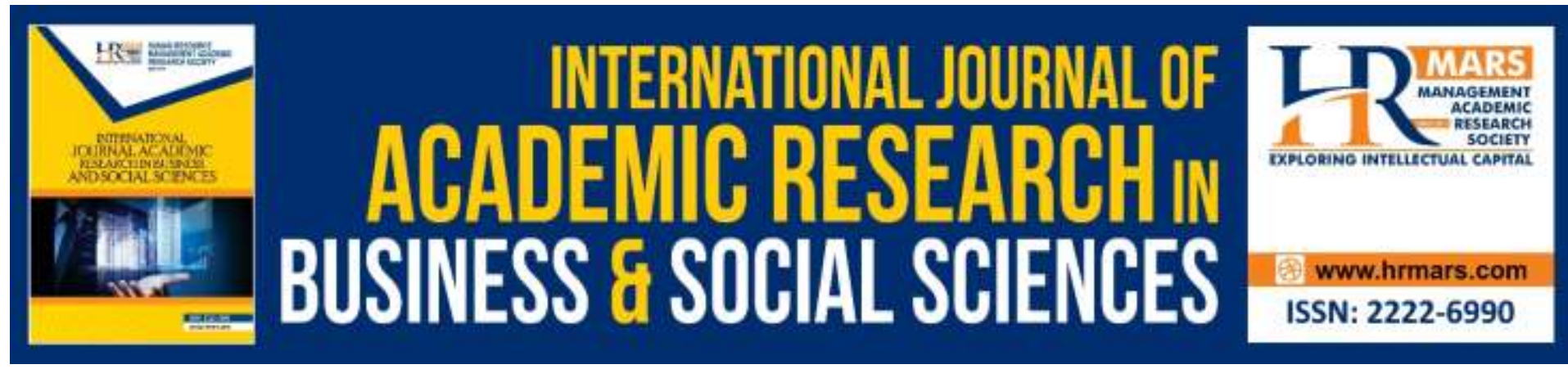

\title{
Indie Phenomenon: Sustainability of Malay Literature
}

\author{
Sim Chee Cheang \\ University Malaysia Sabah, Malaysia
}

\begin{abstract}
With the emergence of Malay Indie works such as novels, short stories and poetry appearing in social media streams such as Facebook and Twitter accounts, many critics are torn between lambasting it as "trash" or lauding it as creative measures to rejuvenate a dying reading habit among the new millennia generation. The so-called "Indie" writers write novels, short stories or poems based on their own opinions in a language that is not in accordance with the level expected of Dewan Bahasa Pustaka. These works have indeed rejuvenated the reading trend among the younger generation and is credited with giving new breath to Malay literature with the increasingly sophisticated mainstream Malay Literature becoming out of reach of the general public. The majority of the adolescent followers whose enamoured relationship with the world of technology has been the bane of all the parents, have suddenly been captivated with these Indie publications. Their increasing interest in reading these books because of the low cost and easy access plus quick release compared to mainstream literature has sustained these publications. Utusan Malaysia Literary column (March 27, 2016) regards the emergence of these Indie works as a phenomenon due to changes in society. This article will examine how far the emergence of these works is a contingent phenomena especially in the arena of Malay literary development through a comparative comparison of the mainstream Malay Literary and Indie works that are concurrently published in the 1990s.
\end{abstract}

Keywords: Malay, Indie Works, Literary, Phenomenon

\section{Introduction}

According to Adi Namri Sidek at in his article entitled "5 Penerbitan Buku Indie paling Cemerlang di Malaysia" (Namri, 2016), the increase in the reading habits of Malaysians from one page in 1997 to 8 books in 2010 due to the publication of Indie Malay Literature is a claim that should be seriously investigated through valid academic research. His claims appear to be unfounded based on Salim Md Zain's statistical report on the reading habits at Dewan Bahasa Pustaka's site entitled Budaya Ilmu dalam Kalangan Rakyat Malaysia. Although there is a significant increase in the number of books read by Malaysians but what is read are mostly comics, magazines and news. Based on the research by Perpustakaan Negara Malaysia (PNM), from between 1996-2005, there is no significant changes in the reading habits of Malaysians when compared to other countries. However, the rise of Indie publishers like Fixi, Lejen Press, Gerak Budaya, Dubook Press and Sindiket Soljah is undeniable. 
The working definition for "phenomenon" in this research refers to the English Cambridge definition of it as "something that exists and can be seen, felt, tasted etc., especially something unusual or interesting". The keywords are "something unusual or interesting" which in this case refers to the emergence of Malay Indie literature amidst the mainstream literature mostly published by private small start-up companies against Dewan Bahasa Pustaka who holds the monopoly. What makes it unusual is the lack of demand from decreasing readership of printed material as mentioned against a mushrooming of Indie publishers and their works in the market. It appears to be a social phenomenon as these Indie publications have attracted the younger generation who view these writings as Bernama.com (2016 Jun 9) reports a form of freedom from a suffocating lackluster publishing industry (trans. "kelesuan dan kesenduan industri buku" )

"Indie" in this research is derived from the original term "Indie" with reference to independent companies who barter music, film or movies away from the mainstream ideas (Cambridge English Dictionary, 2019) of the arts. In this research "Indie" refers to literature in particular novels published by independent companies as mentioned above who have their own "rules", vision and set of criteria or rather free in form and expression. [5] The emergence and proliferation of the Indie publishers has generated a division among readers and publishers which increases its phenomenality. It was Hussin (Utusan, 27 Mac 2016) in his literary column who labeled the rise of the Indie works as a phenomenon [...sejenis penulisan baru yang digelar sastera atau penuilsan Indie telah menjadi sebuah fenomena]. The phenomenon is spurred on by the mark difference between the Indie literary works and mainstream literature.

The criteria for the assessment of Malaysian literary works which is the Hadiah Sastera Perdana established 26 years ago by Razak in 1971 in his efforts to improve the quality of Malay literature (Siti Irni, 2018 January 20), includes a systematic and responsible critical discourse of literature; the accurate and relevant use of theory/concept or critical concept; the originality and maturity of the work that showcases something new; and the validity of the details in terms of facts and explanations to support the analyses of the subject (Mimbarkata, 2018). The criteria listed by the panel of critics and academics plus writers can serve as a description of the mainstream literature.

Against this is the description of the Indie novels by various critics who either laud it as a free expression, an alternative cultural discourse for the younger generation that is easily accessible (Muhammad Febriansyah 2016: 46) and a "fresh presentation" [persembahan yang segar] like Dr. Hani Salwah Yaakup who lambasted it as "rude vomit for self satisfaction...to fulfill the appetites of a people" [luahan mentah, syok sendiri, merapu, biadap...memenuhi selera dan permintaan masyarakat] (Azman Hussin, 2016 March 27). The Chairman of Dewan Bahasa Pustaka, Datuk Seri Md Saleh Yaapar, reiterates these concerns when he implies that Indie works can destroy the Malay language and the Malay identity [karya 'indie' boleh merosakkan bahasa Melayu dan jati diri bangsa Melayu] (Harian 2016).

This research explores the claims of these opposing forces against the history of Malay Literature focusing specifically on the novels published by the mainstream in comparison with the Indie novels that appeared in the late 1990s and early millennium. Its objective includes:

i. Assessing the novels themes against the author's current social cultural background

ii. Analyzing the writing techniques of the novels

iii. Uncovering the similarities between these novels

iv. Exposing the differences between these novels 
v. Identifying the function of these texts as part of a continuum with other publications of a particular time

\section{Methodology}

\begin{tabular}{|c|c|c|c|c|c|}
\hline NO. & $\begin{array}{l}\text { WRITE } \\
\text { RS }\end{array}$ & NOVELS & YEAR & \multicolumn{2}{|c|}{ NARRATIVE STYLE } \\
\hline 1. & $\begin{array}{l}\text { Shahno } \\
n \\
\text { Ahmad }\end{array}$ & $\begin{array}{l}\text { Lamunan } \\
\text { Puitis }\end{array}$ & 2002 & In search of the & Poetic Realism Malay identity \\
\hline 2. & $\begin{array}{l}\text { Faizal } \\
\text { tehrani }\end{array}$ & $\begin{array}{l}\text { Bedar } \\
\text { Sukma } \\
\text { Bisu }\end{array}$ & 2006 & $\begin{array}{l}\text { The glorious } \\
\text { Malay Civilization }\end{array}$ & Magic Realism \\
\hline 3. & $\begin{array}{l}\text { Malim } \\
\text { Ghozali }\end{array}$ & Daun & 2008 & Philosophy of truth & Post-moden \\
\hline 4. & $\begin{array}{l}\text { Kamalu } \\
\text { din } \\
\text { Endol }\end{array}$ & $\begin{array}{l}\text { Baldatu } \\
\text { Thoiyyiba } \\
\text { tun }\end{array}$ & 2010 & Islamic Utopia & Sci-fi Fantasy \\
\hline 5. & $\begin{array}{l}\text { Anwar } \\
\text { Ridhwa } \\
n\end{array}$ & $\begin{array}{l}\text { Penyeber } \\
\text { ang } \\
\text { Sempada } \\
n\end{array}$ & 2012 & Quest for freedom & Unconventional \\
\hline
\end{tabular}

To understand the sudden appearance and the flourishing of Indie Malay literature and independent publishers at the beginning of the millennium is to analyze the point of change or the beginning of the phenomena in Malay literature historiography particularly at the turn of events which critics loosely claim was between 1990's and the millenia. This research adopts a qualitative approach through a New Historicist perspective to the interpretation of the analyses which views a text as a reflection of the social cultural landscape from the author's perspective of his or her time. Although Stephen Greenblatt asserts that his approach will provide a deeper perspective of the cultural context of a literature, this research hopes to show that a better understanding of the narrative styles and preferences of the authors and their critics who are often in disagreement are merely cultural poetics (Veenstra, 1995) that is ironically crucial for the sustenance of a literature. According to Greenblatt "a text is informed by the same cultural dialectics as the society at large" (Veenstra, 1995:180) or simply put "culture is a text" because it is a product of its surroundings. This approach does not support the relativity of all truth especially in reference to history (Curthoys, 2019) but rather views fiction as the gaps and fissures that fill in-between history as touted by Foucault's perception of fiction as textual history. The textual history reflected in creative works such as novels in this research which reflects both technically and in context the transition from a previous cultural divide courtesy of recent political upheaval experienced by a country situated at the initial stage of change to the social millennial ethos.

As such a list of highly acclaimed novels that received the national literary award by Dewan Bahasa Pustaka and the Indie novels or short stories that sold most copies recommended by critics from between 1990s and the millennium will be analysed, compared and interpreted taking into account the political and cultural influences of the time these works were published. Since there were few Indie novels published at the rise of the Indie 
publication earlier popular publication of short stories such as Rubina (2008) is included in the analysis. To ensure a fair comparison between the two strains of Malay literature, namely the mainstream publications (Table 1 ) and the Indie publications (Table 2), the analysis will focus on two variables that is the thematic concerns and narrative styles of both streams of publication. The themes and narrative style of each work will be uncovered and then compared to find similarities and differences between them taking into account the social political conditions of the time of publication of both streams of works. The findings will reflect a majority or minority of similarities or differences between the thematic concerns and the narrative styles of both streams of publication leading to a conclusion indicative of the position of Indie literature in the Malay Literature ethos at the dawn of the millennia age.

The themes were assessed based on type, complexity and intention pertaining to the social political scene that influenced the writing or the writer while the narrative style was assessed through the type of language used, technique and stand of the writer. Each of these components were than summarized according to the two streams of literature to be compared on a general level to identify the position of both streams of literature in the Malay Literature Ethos.

Table 1 Mainstream Malay Novels (2000-2011)

\begin{tabular}{|c|c|c|c|c|c|}
\hline No. & WRITERS & NOVELS & $\begin{array}{c}\text { YEAR } \\
\text { PUBLISHED }\end{array}$ & THEMES & $\begin{array}{l}\text { NARATIVE } \\
\text { STYLE }\end{array}$ \\
\hline 1. & Sufian Abas & $\begin{array}{c}\text { Kasut Biru Rubina } \\
\text { (Dubook P) }\end{array}$ & 2008 & Whimsical Life & $\begin{array}{c}\text { Experimental } \\
\text { (Diary) }\end{array}$ \\
\hline 2. & $\begin{array}{l}\text { Saifullizan } \\
\text { Tahir }\end{array}$ & Kasino (FIXI) & 2011 & Political Hipocracy & Satire \\
\hline 3. & $\begin{array}{l}\text { Ridwan } \\
\text { Saidi }\end{array}$ & Cekik & Mei 2011 & Reality of Appetites & $\begin{array}{l}\text { Destruction } \\
\text { of Innocence }\end{array}$ \\
\hline 4. & & Amerika & Sept 2011 & $\begin{array}{l}\text { Social \& economic } \\
\text { Disparity among } \\
\text { Malaysians }\end{array}$ & $\begin{array}{l}\text { Humour \& } \\
\text { Symbolism } \\
\end{array}$ \\
\hline 5. & & Stereo Genmai & Jun 2011 & Truth in primordial & $\begin{array}{l}\text { Intellectual } \\
\text { Islamic } \\
\text { Discussion }\end{array}$ \\
\hline
\end{tabular}

Table 2 List of Malay Indie Novels published 2000-2011 


\section{Discussion}

Themes: Lamunan Puitis which is the last novel by the celebrated father of modern Malay Literature Shahnon Ahmad is a trilogy that consists of "Sebuah Mimpi Hari Tua" about a modern family reminiscing about the old folks and the abandoned paddy fields in their "kampung" while the second book entitled "Titipan" relates metaphorically how the persona misses his mother and the third entitled "Embun" tells of how the persona tries to differentiate himself for the masses just as a dew drop differs from rain. The theme is clearly about the loss of the old-ways and the need to create a new Malay identity symbolically by the father of Malay Literature who passed away after this novel was published. This type of grand romantic nostalgia is not found in the Indie writings. Other award winning entries like Bedar Sukma Bisu resonates the call to Malaysians to return to the glory days of "Tanah Melayu" that was much sought after for its rich land and position in South East Asia through a post-modern narrative of a fictional world of Wefada, the main character in a land symbolically reffered to as "Semenanjung Emas". However, Faisal Tehrani's novel differs from Shahnon Ahmad's novel in that it identifies the destroyers of the land implicating the citizen's themselves which leaves the reader with anger rather than a sense of loss in Shahnon's novel.

Amidst this idealistic sense of nostalgic loss that is reiterated in the the mainstream novels, the first collecion of 37 short stories Rubina (2008) by Sufian Abas published by Indie publisher Dubook, features all the weird anecdotes of life that includes unicorns, astro travel and strange mites protruding from the anal region. The oxymoronic deviance between the two types of literature can be perceived from a "cause and effect" relationship that rules out the existence of one without the other. While Shahnon and Faisal as well as Daun (2008) implies through their nostalgic or philosophical themes of the loss of "truth", humanity and especially the Malay identity to hard politics and corrupt power, Sufian Abas' short stories and Kasino (2011) by Saifulizan Tahir demonstrate the consequences of that loss. After the 2008 electoral polls, the emergence of Indie movement became stronger with demonstrations of defiance against the newly elected government through the arts specifically by the younger generation (Ismail, 2016).

Narrative styles: Delivered in simple language, often with spelling or grammatical errors and deliberate use of slang (Wahab, 2017) the Indie novels show of defiance against the mainstream publishers or Dewan Bahasa Pustaka through the destruction of Bahasa Melayu led to Indie publishers being synonymous with political protest. There is a bold claim that the Indie works represent the Y generation's reaction to the political corruption that they felt was ruining the economy and the lives in the city as well as in the interior (Hussin, 2016). The writings which are often morbid, ghoulish, melancholic, gruesome and grim is actually a "reflection of society" [cerminan apa yang ada dalam masyarakat] (Bernama, Lifestyle \& Youth 2016). However, Febriansyah (2016) points out that Indie publications already existed before the 2008 electoral polls in the form of "Gerakbudaya" and Silverfish publishers that were both established in 1998 and 2002 respectively. They were categorized as Indie as they published independently in a DIY fashion that meant no vetting from government bodies.

The difference is in the voice of protest that is emphasized in majority of current Indie publications in comparison. The type of publications that appeared after Indie presses like Lejen, Dubook, Fixi, Sindiket Soljah were united in challenging ethical, moral and religious norms as demonstrated in Cekik (2011) by Ridhwan Saidi and his other novel Stereo Genmai (2011). While Cekik (2011) details the unwholesome coming off-age of Warith who is invloved 
with his 32 year old lecturer and discovers the mental torture by a man he thought was his father is not his father as a result of his mother getting raped. Life is just a complicated quagmire experience equated to living like a cockroach in squalor and never deserving any better as depicted in Stereo Genmai (2011). The themes and narrative style leans heavily toward absurdisme and nihilism that is evoked through hedonistic characters and plots such as T Kasino (2011) (Wahab, 2017).

Adversely, Shahnon's trilogy is intricately phrased in nostalgic verse recalling the styles of classical Malay literature in order to emphasize the role of his novel in the face of a rapidly declining culturally rich Malay backdrop. Daun by Gozali Malim is also touted to be philosophical but filled with lyrical poems in between the sophisticated story-within-a-story narrative about a lecturer Sifar who is writing a novel. The questions about truth, religion, love and nostalgia is bound together through a universal philosophy of life begetting another life. But Shahnon Ahmad was 73 when he published Lamunan Puitis (2003) and nobody can forget his phenomenal Ranjau Sepanjang Jalan (1966). Similarly, Gohzali Malim was 59 when he published Daun (2008), while Kamaludin Endol published his critically acclaimed Baldatun Thoiyyidun (2012) at 55 and Anwar Ridhwan was 63 when Seberang Sempadan (2012) was published. Aside from the fact that the Indie writers like Sufian Abas, Saifulizan Tahir and Ridhwan Saidi are all below 35 years of age and Indie works are a reflection of the younger $Y$ generation mind-set (Wahab, 2017), there are similarities. They the same goal in publishing which is to bring change to the nation. We have not forgotten that Shahnon Ahmad's novels championed the people's causes conventionally and unconventionally, in fact controversial ways with his novel SHIT (1999) when he was affected by his personal involvement with local politics during his younger days. Each of the mainstream novels put entertainment value second to change for a better future. Seeking controversy for attention appears to be a tactic shared by both streams of writers too as demonstrated in the Indie novels' loud, error ridden publications. It is obviously not unfamiliar to the mainstream authors as well who themselves have resorted to this tactic in their earlier publications as mentioned above.

Differences between the narrative styles is also evident between novels in the same stream. From a more conventional narrative in poetic resonance of Lamunan Puitis (2002), four years later there is Membisu (2006) by Faisal Tehrani, a magic realism novel followed by a post-modern novel Daun in 2008 by Malim Gohzali and later a science fiction endeavour by Kamaluludin Endol entitled Baldatu Thoyyibatun in 2010, not to mention Anwar Ridhwan's excursion into experimental technique in his recent novel entitled Seberang Sempadan (2012). The magnificent creative flair in these novels do not reflect the charges of "fatigue" and "confusion" that has been leveled at mainstream novels such as these. (Bernama, Lifestyle \& Youth, 2016).

The ability to include the same mesages carried by the Indie novels within an aesthetic framework that lives up to creative writing as an art form is easily proven through the length and breath these writers go to tell the story. Similarly, there exist differences between the novels in the Indie stream with different publishers like Fixi declaring that they"like making money" (Febriansyah 2016) and they represent "marginal voices" as claimed during a gathering of wirters in Jitra, Kedah in 2014. Indie writing is purported to be divided into writings described as "Indie putih, indie fikrah and Indie Tarbiah" (Bernama, Lifestyle \& Youth, 2016) based on different genre(s).

The main differences between the mainstream and the Indie writers today lies in their technique of delivery of their works. The Indie writers believe that they are introducing or 
uncovering "truth" against idealistic lies couched in sacarsm, insults, provocative language (Ismail, 2016). They deliver their messages about life and love without art, laying it bare without embelishments like an expose which may hurt the sensibilities of authority but achieves their objective which is to draw attention to the condition that ironically has been set for them by the mainstream writers and their works prior to their emergence. The mainstream literature do not focus on the ugliness of the "now" but encourage change through the creation of ideal alternatives. They create hopeful posibilities of a better future like Baldatun Thoyyidun's (2008) Islamic Utopia in 2020 by Kamaludin Endol. They encourage a new universal wider, larger and more mature perspective of the past to change the conditions of the present as encouraged by Anwar Ridhwan's novel entitled Seberang Sempadan (2012) where he uses the backdrop of communist Malaya to deliver his message of struggle for freedom with different characters and fictional plot.

\section{Limitations of the Research}

The conclusions to this research is applicable only to the thematic and narrative styles analysis of the Malay novels genre within the period of study. It is not represensative of the entire corpus of Malay Literature either in the mainstream or Indie. Since there have been two strands of critical opinion in regards to the emergence of Indie Malay literature, the results of this comparative research between selected novels focussing on the differences between the novels in both streams reveal that there are obvious similarities and differences between the novels themes and narrative styles only. Conclusions are made based on the interpretation of these differences against the social-political awareness of the times the works were published.

\section{Conclusion}

The differences and similarities between the themes and narrative technique in the mainstream and Indie novels do set them apart especially in terms of technique more than thematic concerns. But disparity is also detected between the types of novels within a single stream making the claims on thematic and narrative differences between streams difficult to establish. However, one strong singular similarity that is shared by both streams is the shared purpose for change in both the mainstream and Indie works. This shared thematic similarity appears to have been set by the mainstream writers and their novels, considering the full length novels appeared earlier than those in the Indie stream and experimental controversial techniques having been utilized earlier by some of the mainstream novelist themselves. As such, the Indie stream of Malay works is a change or a consequence of the change that has been ironically heralded and foretold by the mainstream literature making the Indie phenomena a non-event. From a New Historicist perspective, there is no phenomena but merely a literature responding to the social-political changes of the times just as all the novels and novelist have different themes and explore different techniques of the art of writing reflecting the their thousgts and experiences of the times they lived in. "Controversy" is but another narrative tool used by both streams to draw attention and help market the works through different strategies. The purpose for publication remains the same as both streams intend to provide food for the soul and entertainment through writing. Therefore the the Indie works should merely be perceived as a sustainable method to ensure that Malay literature continues to thrive inspite of the controversial narrative styles, themes and negative critique. 


\section{References}

Sidek, A. N. (2017). "5 Penerbitan buku Indie paling cemerlang di Malaysia". https://iluminasi.com/bm/5-penerbit-buku-indie-alternatif-paling-cemerlang-dimalaysia.html

Hussin, A. (2016). "Sastera karya Indie umpamagrafiti." Utusan.com. http://www.utusan.com.my/pendidikan/sastera/karya- indi-umpama-grafiti

Bawer, Bruce. (2017) "What is New historicism?". New Criterion. https://www.cliffsnotes.com/cliffsnotes/subjects/literature/what-is-new-historicism. September Vol. 36 (1), pp. 1.

Berita Harian, Hiburan (2016) “DBP bimbang penulis muda terpengaruh karya 'Indie' http://www.astroawani.com/berita-hiburan/dbp-bimbang-penulis-mudaterpengaruh-karya-indie-99160

Bernama, Lifestyle \& Youth. (2016 June 9). "Karya Indie dan industri penerbitan buku di Malaysia". http://web10.bernama.com/Iny/v2/news.php?id=1253819\&c=6

Cambridge English Dictionary. (2019) https://dictionary.cambridge.org/

Curthoys, Ann., \& Docker, John. (2019) Evatt Foundation Papers. Review. "The necessity for and difficulty of finding the truth in history". https://evatt.org.au/papers/historyfiction.html

Dimensi pencorak pemikiran asas. (2016) "Kebangkitan, ledakan karya Indie". http://dimensinews.com.my/2016/06/13/kebangkitan-ledakan-karya-indie/

Mimbarkata. (2013) "Hadiah Sastera Perdana Malaysia". http://mimbarkata.blogspot.my/2013/06/hadiah-sasatera-perdana-malaysia.html

Mimbarkata (2018) "Hadiah Sastera Perdana Malaysia"

http://mimbarkata.blogspot.my/2013/06/hadiah-sasatera-perdana-malaysia.html

Morgan, Pen, K., \& the Pad. (2019) Pen \& the Hand. "How does fiction mirror society?" https://penandthepad.com/fiction-mirror-society-19310.html

Febriansyah, M. (2016). “Penerbit buku Indie: Benarkah anti-arus perdana?. Dewan Sastera (November), pp. 46.

Ismail, N. H., \& Yusoff, M. F. M. (2016). "Karya Indie: revolusi penulis generasi baru". Proceedings of ICECRS, (1): 567. DOI: https://doi.org/10.21070/picecrs.v1i1.526

Wahab, R. (2017). "Karya Indie:mencari antara permata dan kaca". Utusan online. http://www.utusan.com.my/pendidikan/sastera/karya-indie-mencari-antarapermata-dan-kaca1.489310.

Mosman, S. I. Y. (2018 January 20). "Hadiah Sastera Perdana Malaysia Pengiktirafan Tertinggi di Malaysia". http://klikweb.dbp.my/ 